de Trabalho.

Trabalho \& Saúde, órgão oficial do DIESAT, é uma publicaçāo preocupada em apresentar questōes referentes às condições de trabalho e à saúde dos trabalhadores brasileiros, quaisquer que sejam suas áreas de atuação. Voltada ao movimento sindical, interessa também a pesquisadores, técnicos e todos aqueles que se interessam pela segurança e proteçảo à saúde e bem-estar dos trabalhadores brasileiros.

Assinaturas podem ser solicitadas ao: DIESAT Revista Trabalho \& Saúde Rua Das Carmelitas, 149 $3^{\circ}$ andar - 01020 - São Paulo - SP - Telefone (011) 36-1101

Cultura contemporânea O CEDEC - Centro de Estudos de Cultura Contemporânea - associação dedicada à pesquisa na área de Ciências Humanas, tem por objetivo promover estudos multidisciplinares sobre a sociedade brasileira e outros países da América Latina. Possui um setor de documentação cujo acervo conta com um farto material sobre Movimento Sindical, Partidos Políticos, Movimentos Sociais Urbanos, Violência e Igreja, além de coleções de revistas extintas como Civilização Brasileira, Brasiliense, Cadernos do Nosso Tempo e Anhembi. O Cedec/Documentação está à disposição dos interessados na troca de material e aceita doações.

CEDEC

Rua Adolfo Tabacow, 201 01453 - São Paulo - SP Telefone: (011) 210.1987.

\section{Debatendo os testes psicológicos}

\author{
Jairo E. Borges Andrade
}

D.

A revista Arquivos Brasileiros de Psicologia publicou, no número 2, volume 37 , o artigo Os testes psicológicos em seleção de pessoal, de Wedher Modenezi Wanderley, psicólogo do ISOP.

$\mathrm{O}$ artigo "questiona conceitos e procedimentos que orientam o emprego dos testes psicológicos em seleção de pessoal. Examina levantamentos de pesquisas realizadas com testes para as ocupações, concluindo pela inexpressividade dos resultados (o grifo é nosso).

A interpretação dada, nos referidos testes, às características psicológicas, é considerada, pelo autor, como irreal. Ele "insiste na comprovação do relacionamento teste-desempenho antes de o preditor ser utilizado para fins decisórios" (o grifo é nosso). Além disso, é analisada a inadequação dos vários conceitos de validade dos testes.

São citadas as "restrições ao uso dos testes, impostas nos EUA, pelo governo e pelas cortes de justiça" e mostrada a necessidade de os psicólogos brasileiros elaborarem normas rigorosas para o emprego de testes, antecipando-se às restrições legais que inevitavelmente surgirão (nosso grifo), depois que forem feitos alguns recursos à justiça.

A leitura do artigo leva à reflexão sobre o uso que é feito dos testes psicológicos em seleção de pessoal, quando tomamos decisões que podem afetar irremediavelmente a vida dos indivíduos. A publicação do artigo, feita por um periódico e uma instituição que desempenharam um papel tão importante na história dos testes no Brasil, é excelente ocasião para abrirmos um debate sobre o assunto.

Ressaltamos ainda algumas conclusões, que merecem destaque:

1 -... "não existe base lógica ou científica para atribuirmos a categorias descritivas de comportamentos observáveis - como as atuais aptidões e os traços de personalidade existência própria, independente dos testes que lhes deram origem".

2 - "Se a linha de pensamento seguida pelo psicólogo o levar a presumir existirem atributos latentes que se refletem na resolução das questões do teste e no desempenho das tarefas do trabalho", este psicólogo tem a obrigação de comprovar cientificamente essa hipótese, “... porém, para cada teste, antes de utilizá-lo na tomada de decisões em relação às pessoas".

3 - ... "os testes empregados devem ser desenvolvidos ou escolhidos após (nosso grifo) terem sido elaborados os critérios e a partir deles."

4 - É um erro acreditar que se pode considerar um teste validado, se - correlacionamos com o critério, pois a validade de um teste é a sua capacidade de medir aquilo a que ele se propõe. $O$ que se tem feito com os testes na pesquisa em seleção não corresponde ao conceito de validação que citamos acima.

5 - "Os testes baseados na amostragem de conteúdo (o grifo é nosso) constituem, geralmente, a solução mais adequada à seleção de pessoal, sempre que puderem ser desenvolvidos." A qualidade desse tipo de teste vai naturalmente depender de uma série de fatores, tais como uma adequada análise do trabalho, uma identificação correta do domínio de conteúdo e a representação desse conteúdo no teste.

6 - "Ser avaliado de acordo com a sua real capacidade para exercer o cargo é um direito do individuo, um dever da organização e uma necessidade da sociedade." (os grifos são nossos). Além disso, gostaríamos de acrescentar, à conclusão feita pelo autor, que essa avaliação é uma obrigação ética do psicólogo. $\mathrm{O}$ autor crê que é aconselhável que, no Brasil, a nossa profissão se antecipe às restrições legais - começando, por exemplo, com os psicotécnicos “elaborando normas rigorosas relativas ao uso dos testes psicológicos em seleção de pessoal, mantendo, desse modo, o controle da situação."

Vamos ler o artigo e debater as questões e os problemas que ele nos coloca. Vamos discutir, de maneira científica e politicamente responsável, as alternativas de solução. Ou vamos esperar para ver o que vai acontecer? Cabe a nós exercitarmos uma política oportunista a curto prazo, ou legislarmos preventivamente? 